\title{
Reflective Thinking for Quality Mathematics Instruction: A Study on Fiji Primary School Teachers' Knowledge of Reflective Teaching
}

\author{
Submitted 1 November, 2021 Revised 22 November 2021 Accepted 23 November 2021 \\ ${ }^{1}$ Taraivini Raramasi Raiula, ${ }^{2}$ Vijayakumari. S.N., ${ }^{3}$ Victor M. Alasa*, ${ }^{4}$ Sereima Takiveikata, \\ ${ }^{5}$ Awadhesh K. Shirotriya \\ ${ }^{1,3,4,5}$ School of Education, College of Humanities \& Education, Fiji National University, Lautoka, Fiji \\ ${ }^{2}$ St Ann's College of Education (Autonomous), Mangalore, India \\ Corresponding Email: *victor.alasa@fnu.ac.fj
}

\begin{abstract}
This study was aim at analyzing the notion of quality teaching expected of teachers as reflective practitioners, which are continuously articulated during workshops, conferences, however, its practicality seems vaguely defined and at times, reflection seems to lose its purpose and value. The study engaged a descriptive survey which used stratified sampling technique which understudies 363 Primary School Teachers in Fiji from the four major Education Divisions, in which each stratum was selected. A 'Test on Knowledge of Reflective Teaching,' and a 'Rating Scale on Practice of Reflective Teaching' were conducted and analysed to compare the components of Knowledge and Practice of Reflective Teaching, with respect to teaching experience, and the data was analysed quantitatively using Analysis of Variance (ANOVA). Fndings from the study amongst others is that there is a significant difference in knowledge which focus on practical aspects' component of knowledge of reflective teaching for primary mathematics teachers in Fiji.
\end{abstract}

Keywords: Knowledge of reflective teaching, Reflection based on the Learner, Reflection based on the Teacher, Reflection based on Practical Aspects, Reflection for Action

\section{INTRODUCTION}

Reflective teaching, according to Dewey (1933), includes a reflective exercise whereby one tries to organise one's thinking in a more organised way on how to overcome confusing or troubling situations, and such approach normally connects theory to practice. In the teaching profession, one is faced with varied situations continuously, and addressing them involves interaction with students, work and engagement with colleagues, school and communities. Dewey also added that through interaction, teachers need to take action and these come with responsibility and open mindedness. Through reflection, one could be motivated to try out new approaches for better practice and that would involve action research. Therefore, 'there is a need to inspire prospective and practising teachers to develop critical thinking and reflective practice which results in transformative learning which is the need of the hour' (Kumari, 2014:38). Some of the merits of reflections, according to McKay (2002), and Larrivee \& Cooper (2006) are; shifting away from textbook teaching; understanding different theoretical basis which drives classroom practice; connecting the gap between assumptions and beliefs about teaching and learning with what one actually does; thus connecting theory to practice.

Reflection engages a teacher in a systematic, demanding and disciplined thinking about professional practice and involves a process of self- observation and self-evaluation. It needs to 
be viewed as an active and thoughtful mental process involving sequences of inter-connected ideas that take into justification underlying beliefs and knowledge (Dewey 1933). Reflective teaching demands teachers to develop critical thinking skills in order to evaluate past (Reflection on Action), and current practices (Reflection-in Action) to improve one's practice for future decisions (Reflection-for Action) Farrell (2004). When teachers are exposed to this refined cognitive process, it would bring open-mindedness thus, not only the students would gain knowledge, it would also bring about collaborative work for students and teachers hence create new knowledge through simple action researches. Through reflection, and new challenges faced in teaching, teachers would be curious to experiment new approaches to order to tackle such challenges, thus increasing new knowledge in teaching and learning which would bring about self-satisfaction and excitement for both teachers and students.

Fat'hi \& Behzadpour (2011) viewed the major aspects of reflective teaching as; firstly, reflections need to be based on the learner, with students' cognitive development with related learning styles; secondly, reflections need to focus on the teacher, which focus on teachers' personality, background, values and beliefs; thirdly, reflections which focus on practical aspects which focus on its different forms, such as journal writing, observation, group discussion, and others. Fourthly, reflection based on teachers' cognitive development focusing on one's professional development, such as conducting small scale researches, action research, and small classroom projects. Furthermore, reflections based on critical or contextual development aspect of practice, which includes reflections related to a teacher's intellectual abilities and one's practice, thus considering relationship between individual teaching actions and the role of education in the society. Finally, the focus of reflection covers moral or ethical parameters refers to reflection which includes teachers' critical thinking about their purposes and justifications; relational approach, which includes philosophies that emphasize on personal characteristics, and effective social interactions; and reflections that claim a voice of their own, as students.

There has been considerable work carried out in trying to associate reflective teaching with quality instruction in Primary mathematics, which is well documented in international literature, and is yet to be explored in Fiji's context, which is the focus of this study. Secondly, since Fiji is categorised as a "Small Island State' with a population of about 900, 000, findings of such studies, according to Sanga (2012), could be used as building blocks of local and international literature in mathematics education. The work of Salifu et al (2017) highlights the significance of reflective teaching on students' performance, which engaged university staff in Ghana, and findings revealed there were differences on views on reflective teaching activities, 
International Journal of STEM Education for Sustainability, Vol 2, No.1, 2022, pp. 32-44

e-ISSN 2798-5091. DOI. 10.53889/ijses.v2i1.36

lesser emphasis on clinical enquiries and moral crafting, and no interest in technical -oriented teaching and self- analysis. Findings revealed that teachers engaged in reflective teaching showed effectiveness in teaching and indirectly contributes to students' positive learning outcomes.

Critically analysing different reflective methodologies from secondary data from the study carried out by LaBelle (2017) revealed that genuine interactive classroom practices are well articulated using reflective writing, peer critique and observation, peer-videos, structured video analysis and reflective dialogues which could be categorised under knowledge which Focus on Practical aspects. The study carried out by Erixon (2016) on the significance of online oral mathematics discourse among teachers' reflections on practice revealed that such form of discourse is effective, however, narrowly focussed on general mathematics teaching and not on the core issues of teaching mathematics. Other drawbacks for this mode of dialogue are; no eye contact, absence of body language, and nature of dialogue, can be highly structured that takes away the essence of real dialogue by taking turns, and no disruptions within dialogues.

Taylan \& da Ponte (2016) focussed on how interaction and teacher's reflection affect the development of pedagogical reasoning, in terms of instructional strategies and representations and revealed that reflections on students' questioning and misconceptions and interactions have developed teachers' knowledge on teaching and analysis skills for future learning decisions. The experiment conducted by Kumari \& Naik (2015) on the effect of a reflective teaching package for pre-service teachers to identify levels of teaching aptitude and one's interaction on teaching skills, revealed that reflective teaching package is more effective in the development of teaching skills of trainees than the conventional teaching strategy. The notion of reflection helps teachers to take more responsibility to self -reflect and work on the areas of teaching that would need improvement.

Chapman (2015) focussed on the significance of reflective awareness in mathematics teaching, using questioning in inquiry-based teaching and findings revealed that reflective awareness engaged teachers in deeper thinking in matching the situations with appropriate questions, therefore brings a lot of changes in teachers' mathematics teaching and learning new knowledge about inquiry-based approach with related aspects such as questioning. Dogra (2015) revealed that guided reflective journal writing improves teachers' knowledge in teaching, and enhance professional capacity which contributes to better practitioners. Other benefits of guided reflective journal writing are improved in classroom management, content knowledge, varied teaching strategies, interaction, favourable classroom environment, instructional resources, lesson preparations and critical thinking. Chen (2015) revealed that 
engagement of teachers in reflection and preparation of portfolios gave space for gaining mathematical knowledge and teaching methods, therefore suggested proposal for inclusion of reflection using portfolios in teacher education programmes.

Vijayakumari (2014) designed a proposed reflective Interactive Model which could be useful in training pre-service teachers to be effective reflective teachers, familiarising oneself with the different reflective teaching approaches practices and through classroom critical class observations and classroom interaction, improvement of teaching skills would be evident. Sather \& Curl (2014) revealed that reflections through teaching and learning together help teachers to view students' holistic learning, teaching as evolving process built on relationship; the complimentary roles of relationship and engagement in teaching and learning; and to strive for a balance between inquiring whilst respecting students' diverse needs. The experiment conducted by Scherrer \& Stein (2012) on a coding scheme, Analysing Teacher Moves Guide (ATM) which allowed trainee teachers to develop one's ability to notice when engaged in mathematics discourse, and revealed that teacher's ability to notice increased during mathematics discourse and identified different moves teachers use during negotiating students' responses. Kaasila \& Lauriala (2012) tried to examine reflection through mathematics portfolios of pre-service teachers, through reflections on lessons taught, pupil observations, research readings and autobiographies and findings revealed that varied experiences of preservice teachers, were due to differences in prior experience which have affected performances in teaching, and the gap between theory and practice. Barriers of reflections were noted as; lack of motivation and fear of failure, time management and varied expectations of self and others.

After a critical analysis of the related literature findings, the following research gaps have been identified by the researchers; even though reflective teaching is well covered in international literature, there is hardly any literature in reflective teaching for mathematics teaching conducted in Fiji. To fill up this research gap, the present study, titled "Reflective Thinking for Quality Mathematics Instruction: A Study on Fiji Primary School Teachers' Knowledge and Practice of Reflective Teaching" was undertaken.

\section{METHOD}

The number of Primary school teachers in Fiji, according to data collected from the MOE in 2017 was about 7000 teachers. Sample size was calculated from Krejcie and Morgan (1970) sample size Table. The research design used was descriptive survey and the sampling technique used was stratified random sampling in which a stratum from each of the four major Education Division was selected; namely Western, Eastern, Central and Northern. Content Validity was 
used to validate the research tools; hence reliability of the tools was calculated using Cronbach's Alpha of .720.

\section{RESULTS AND DISCUSSION}

The collected data were tabulated, analyzed and interpreted using SPSS Version 16. The data was collected by administering the tool 'A Test on Knowledge of Reflective Teaching' and a 'Rating Scale on Practice of Reflective Teaching' which were analyzed.

Comparison of the Components of Knowledge of Reflective Teaching among Primary School Mathematics Teachers of Fiji with respect to teaching experience

To compare the Knowledge of Reflective Teaching, with respect to teaching experience, the reliability of the data was calculated using Cronbach's Alpha. The detail is given below Table 1. Reliability Details of Data with respect to Teaching Experience Reliability Statistics

\begin{tabular}{cc}
\hline Cronbach's Alpha & N of Items \\
\hline .720 & 6 \\
\hline
\end{tabular}

Hypothesis 1

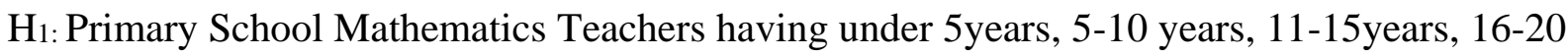
years and more than 20 years teaching experience differ significantly in Components of Knowledge of Reflective teaching.

To test the hypothesis, it was changed into null hypothesis as stated below.

H01: Primary School Mathematics Teachers having under 5years, 5-10 years, 11-15years, 16-20 years and more than 20 years teaching experience do not differ significantly in Components of Knowledge of Reflective teaching.

The hypotheses were tested using one-way 'Analysis of Variance' (ANOVA) with the level significance fixed at 0.05 level. The details are given on Table 1 .

Table 2. ANOVA Details of Knowledge of Components of Reflective Teaching among Primary School Teachers of Fiji with Respect to Under 5 Years, 5-10 Years, 11-15 Years, 16-20 Years, And More Than 20 Years Teaching Experience

\begin{tabular}{|c|c|c|c|c|c|c|c|}
\hline Dimensions & Source of Variation & $\begin{array}{c}\text { ANOVA } \\
\text { Sum of Squares }\end{array}$ & df & $\begin{array}{l}\text { Mean } \\
\text { Square }\end{array}$ & F-Value & P-Value & Results \\
\hline & Between Groups & 5.938 & 4 & 1.485 & 1.074 & .369 & NS \\
\hline \multirow[t]{3}{*}{$\mathrm{FL}$} & Within Groups & 495.059 & 358 & 1.383 & & & \\
\hline & Total & 500.997 & 362 & & & & \\
\hline & Between Groups & 6.841 & 4 & 1.710 & 1.469 & .211 & NS \\
\hline \multirow[t]{3}{*}{ FT } & Within Groups & 416.933 & 358 & 1.165 & & & \\
\hline & Total & 423.774 & 362 & & & & \\
\hline & Between Groups & 12.209 & 4 & 3.052 & 2.664 & .032 & $S$ \\
\hline \multirow[t]{3}{*}{ FP } & Within Groups & 410.160 & 358 & 1.146 & & & \\
\hline & Total & 422.369 & 362 & & & & \\
\hline & Between Groups & 3.334 & 4 & .834 & .942 & .439 & NS \\
\hline \multirow[t]{2}{*}{$\mathrm{FC}$} & Within Groups & 316.622 & 358 & .884 & & & \\
\hline & Total & 319.956 & 362 & & & & \\
\hline
\end{tabular}


International Journal of STEM Education for Sustainability, Vol 2, No.1, 2022, pp. 32-44

e-ISSN 2798-5091. DOI. 10.53889/ijses.v2i1.36

\begin{tabular}{|c|c|c|c|c|c|c|c|}
\hline Dimensions & Source of Variation & Sum of Squares & $\mathrm{df}$ & $\begin{array}{l}\text { Mean } \\
\text { Square }\end{array}$ & F-Value & P-Value & Results \\
\hline \multirow{4}{*}{ FCD } & Between Groups & 4.227 & 4 & 1.057 & 1.280 & .278 & NS \\
\hline & Within Groups & 295.641 & 358 & .826 & & & \\
\hline & Total & 299.868 & 362 & & & & \\
\hline & Between Groups & 1.606 & 4 & .402 & .411 & .800 & NS \\
\hline \multirow[t]{2}{*}{$\mathrm{FE}$} & Within Groups & 349.473 & 358 & .976 & & & \\
\hline & Total & 351.080 & 362 & & & & \\
\hline
\end{tabular}

Table 2 shows that for Knowledge of reflection which 'Focus on Practical Aspects' the F-value is 2.664, and P-value of .032, which is significant at .05 level, thus the null hypothesis, 'is rejected and the research hypothesis, is retained. Hence it can be concluded that there is a significant difference in Knowledge of reflection which 'Focus on Practical Aspects' among teachers with Under 5 Years, 5-10 Years, 11-15 Years, 16-20 Years, And More Than 20 Years teaching experience. However, with respect to Knowledge of reflection which Focus on Learner (FL), Teachers (FT), teachers' Cognitive Aspects(FC), Contextual Development(FCD) and Ethical aspects(FE), they do not differ significantly. This indicates that at least one group is significantly higher than other groups with respect to Teaching Experience. To compare the differences, individual means were identified as given in Table 3

Table 3. Mean and Standard Deviation of Knowledge of Reflective Teaching Components

\begin{tabular}{llllll}
\hline & $\mathrm{N}$ & Mean & Std. Deviation & Std. Error \\
\hline \multirow{4}{*}{ FP } & 72 & 3.1111 & 1.12031 & .13203 \\
& 5-10 years & 78 & 3.4103 & 1.14456 & .12960 \\
& 11-15 years & 68 & 3.1765 & 1.00656 & .12206 \\
& 16-20 years & 76 & 3.4211 & .99684 & .11435 \\
& $>20$ years & 69 & 2.9420 & 1.06942 & .12874 \\
& Total & 363 & 3.2204 & 1.08017 & .05669 \\
\hline
\end{tabular}

To find out which years of teaching experience teachers have which is significantly higher in Knowledge Which Focus on Practical aspects, Post hoc tests was done. The details are given in Table 4 . 
Table 4: Post-hoc Test Results of 'Knowledge which Focus on Practical Aspects' with respect to Teaching Experience of Primary School Teachers of Fiji

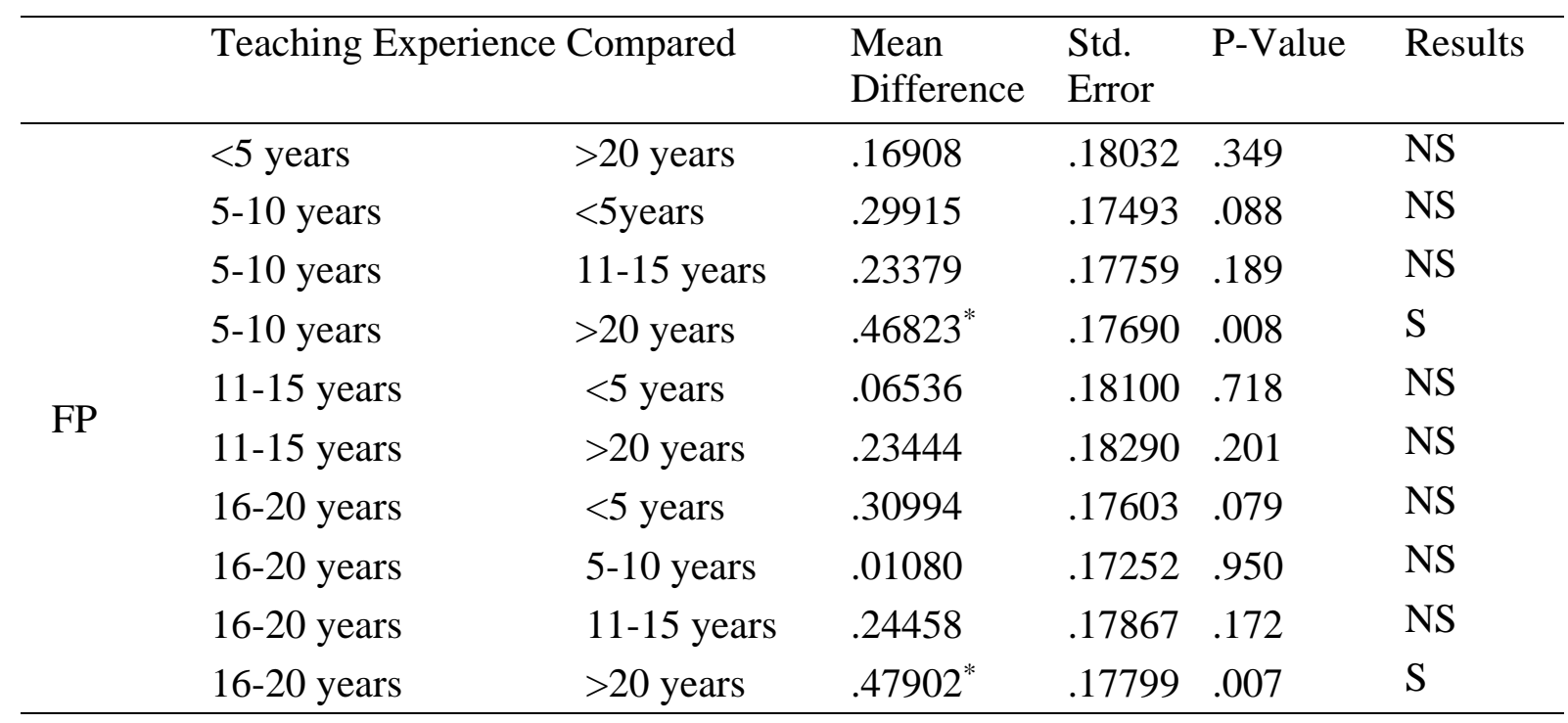

From Table 4 it can be revealed that knowledge of reflection that focus on Practical Aspects of teachers with 5-10 years of Teaching Experience is significantly higher than teachers with more than 20 years of teaching experience with P-value of .008 which is significant at .05 level using LSD post hoc. Hence it can be concluded that 'Knowledge which Focus on Practical Aspects' of teachers with 5-10 years of teaching experience is significantly higher than teachers with more than 20 years of teaching experience. It is also evident from the Table that 'Knowledge which Focus on Practical Aspects' of teachers with 16-20 years of teaching experience is significantly higher than teachers with more than 20 years of teaching experience. However, there is no significant difference in knowledge of reflection that Focus on Practical aspects, between teachers below 5 years and more than 20 years teaching experience, between teachers with 5-10 years and below 5 years, between teachers with 5-10 years and 11-15years, between 11-15years and teachers with below 5 years, between 11-15 years and more than 20 years, between 16-20 years and teachers below 5 years of teaching experience, between teachers with 16-20 years and 5-10 years, and between 16-20 years and 11-15 years of teaching experience.

\section{Comparison of Components of Practice of Reflective Teaching with respect to teaching experience}

$\mathrm{H}_{2}$ : Primary School Mathematics Teachers having under 5years, 5-10 years, 11-15years, 16-20 years and more than 20 years teaching experience differ significantly in Components of Practice of Reflective Teaching.

To test the hypothesis, it was changed into null hypothesis as stated below. 
H02: Primary School Mathematics Teachers having under 5years, 5-10 years, 11-15years, 1620 years and more than 20 years teaching experience do not differ significantly in Components of Practice of Reflective teaching.

Table 5. ANOVA Details of Components of Practice of Reflective Teaching Among Primary School Teachers of Fiji with respect to Teaching Experience

\begin{tabular}{|c|c|c|c|c|c|c|c|}
\hline Dimensions & $\begin{array}{l}\text { Source of } \\
\text { Variation }\end{array}$ & $\begin{array}{l}\text { Sum of } \\
\text { Squares }\end{array}$ & $\mathrm{df}$ & $\begin{array}{l}\text { Mean } \\
\text { Square }\end{array}$ & F-value & P-value & Results \\
\hline \multirow{4}{*}{ RI } & Between Groups & 442.340 & 4 & 110.585 & & & \\
\hline & Within Groups & 24462.073 & 358 & 68.330 & 1.618 & .169 & \multirow{3}{*}{ NS } \\
\hline & Total & 24904.413 & 362 & & & & \\
\hline & Between Groups & 315.443 & 4 & 78.861 & & & \\
\hline \multirow[t]{3}{*}{ RO } & Within Groups & 15778.744 & 358 & 44.075 & 1.789 & .130 & \multirow{3}{*}{ NS } \\
\hline & Total & 16094.187 & 362 & & & & \\
\hline & Between Groups & 254.830 & 4 & 63.708 & & & \\
\hline \multirow{2}{*}{$\mathrm{RF}$} & Within Groups & 13962.266 & 358 & 39.001 & 1.633 & .165 & \multirow{2}{*}{ NS } \\
\hline & Total & 14217.096 & 362 & & & & \\
\hline
\end{tabular}

Table 5 shows the F-value of Reflection in Action is 1.618 and P-value of .169, which is not significant at .05 level, thus the null hypothesis, is retained and the research hypothesis, is rejected. Hence it can be concluded that there is no significant difference in 'Reflection in Action' among Primary School Mathematics Teachers with Under 5 Years, 5-10 Years, 11-15 Years, 16-20 Years, And More Than 20 Years Teaching Experience hence that Reflection in Action is equal among Primary School Mathematics Teachers with different years of Teaching experience. Table 1.5 also shows the F-value of Reflection on Action is 1.789and P-value of .130 , which is not significant at .05 level, thus the null hypothesis, is retained and the research hypothesis, is rejected. Hence it can be concluded that there is no significant difference in 'Reflection on Action' among Primary School Mathematics Teachers with Under 5 Years, 510 Years, 11-15 Years, 16-20 Years, and more than 20 Years teaching experience hence Reflection on Action is equal among Primary School Mathematics Teachers with different years of teaching experience.

Table 5 also shows the F-value of Reflection of Action is 1.633 and P-value of .165, which is not significant at .05 level, thus the null hypothesis, 'Primary School Mathematics Teachers having under 5years, 5-10 years, 11-15years, 16-20 years and more than 20 years teaching experience do not differ significantly in Components of Practice of Reflective teaching,' is retained and the research hypothesis, 'Primary School Mathematics Teachers having different years of Teaching Experience differ significantly in Components of Practice of Reflective Teaching,' is rejected. Hence it can be concluded that there is no significant difference in 'Reflection of Action' among Primary School Mathematics Teachers with Under 5 Years, 5-10 Years, 11-15 Years, 16-20 Years, And More Than 20 Years Teaching Experience. 
Therefore, it can be concluded that Reflection of Action is equal among Primary School Mathematics Teachers with different years of teaching experience.

The review of studies revealed that teachers that engage in reflective teaching show effectiveness in teaching and indirectly contribute to higher student performances (Salifu, et al 2017); allows teachers to upgrade mathematical knowledge and related teaching approaches (Chen 2015); and helps improve teachers' level of effective teaching and interaction on teaching skills (Kumari \& Naik 2015). Some of the forms of reflective teaching which forms the core of practical aspects, are; reflective writing, peer critiquing and observation, video analysis and reflective dialogues LaBelle (2017); journal writing (Thomas \& Kallanakal, 2017); and online oral reflections (Erixon 2016); teachers' collaborative reflection which brings about genuine sharing and in-depth reflections from first-hand experiences of what transpires in real classrooms as highlighted by Hains-Wesson \& Young (2017). Attitude towards reflection is a necessity for effective teaching however, according to Thomas \& Kallanackal, higher percentage of participants are engaged in Reflection- for-Action, compared to reflection-inaction and reflection-on-action.

Moreover, teacher engagement in action research, teaching and learning together bring about holistic student learning and teachers' knowledge (Sather \& Curl 2014). This sort of professional exercise improves chances to develop new practices, increase content knowledge, and familiarize oneself to mechanisms of action research which leads to more researches that focus on teaching practices and enhance reflections based on realistic experiences In addition, in-depth reflection such as noticing (Scherrer\& Stein 2012), Reflection 'in' Action and 'on' Action (Park \& Oliver 2008) are some of the approaches that allow teachers to analyze teaching primary mathematics with an open mind thus reflective practices would contribute to effective teaching.

The present study had revealed that teachers with Knowledge of practical aspects of 5-10 years and 16-20years of teaching experience is significantly higher than teachers with more than 20 years of Teaching experience, in which suggest that teaching experience could be a factor that contributes to effective reflection, which could be further explored. Further investigations could also be carried out on which forms of reflective practices teachers of 5-10 years and 16-20years of teaching experience currently use when teaching mathematics.

\section{CONCLUSION}

If the proposed actions are implemented to address the areas highlighted from the findings of the study, with closed monitoring from the Ministry of Education, the schools would be regarded as the center of learning, for both students and teachers, with totally different 
perceptions from teachers about their teaching, as one teaches with critical thinking, asking the correct questions, analyzing teaching approaches and how students learn, and how to address students' misconceptions. Teachers would begin to develop interest to find out new approaches to teach mathematics if one does not work. Hence, the findings are there is no significant difference on knowledge of reflection which 'focus on the learner'(FL), 'focus on the teacher'(FT), 'focus on cognitive development'(FC), 'focus on contextual development'(FCD), and 'focus on ethical aspects'(FE) components of knowledge of reflective teaching hence equal among primary school mathematics teachers with different teaching experience in Fiji; there is a significant difference in knowledge which focus on practical aspects' component of knowledge of reflective teaching for primary mathematics teachers in Fij and 'Knowledge which focus on practical aspects' of mathematics teachers with 5-10 years of teaching experience is significantly higher than teachers with more than 20 years of teaching experience.

Other findings are, 'Knowledge which focus on practical aspects' of teachers with 16-20 years of teaching experience is significantly higher than teachers with more than 20 years of teaching experience. There is equally no significant difference in knowledge of reflection that focus on practical aspects, between teachers below 5 years and more than 20 years teaching experience, between teachers with 5-10 years and below 5 years, between teachers with 5-10 years and 11-15years, between 11-15years and teachers with below 5 years, between 11-15 years and more than 20 years, between 16-20 years and teachers below 5 years of teaching experience, between teachers with 16-20 years and 5-10 years, and between 16-20 years and 11-15 years of teaching experience. In addition, there is no significant difference in practice of reflective teaching among primary school mathematics teachers with under 5 years, 5-10 years, 11-15 years, 16-20 years, and more than 20 years teaching experience, hence is equal among teachers with different years of teaching experience. There is no significant difference in components of practice of reflective teaching (Reflection in Action, Reflection on Action, and Reflection for Action) among primary school mathematics teachers, with different years of teaching experience. There is no significant difference in practice of reflective teaching components; Reflection in Action, Reflection on Action, and Reflection for Action, among primary school mathematics teachers under 5 years, 5-10 years, 11-15 years, 16-20 years, and more than 20 years teaching experience, hence is equal among teachers with different years of teaching experience.

There is a need for consistent dialogue between MOE and the teacher training institutions in providing professional development sessions on reflective teaching in mathematics for prospective and practicing teachers. In doing so, teachers would spend quality time engaging 
in-depth thinking in order to try out other possible best ways to tackle such tasks. Once the new approaches work, teachers would be excited to share such ideas with other colleagues, maybe during Professional Development sessions and such type of sharing promotes capacity building. Critical thinking would also influence teachers to try out new approaches in the form of action research and more practice would bring about confidence in research. As a result, new approaches are implemented with positive results in students' learning as the lessons would be of great interest with active student participation and these would bring about higher achievements in mathematics for students.

In order to improve the level of Knowledge which is related to Practical aspects for Primary Mathematics teachers in Fiji, with more than 20 years of teaching experience, the Ministry of Education needs to:

- Organise workshops on different forms of reflective tools to improve reflective documentation.

- Provide incentives for teachers who are engaged in research work and publications

- Set up a local mathematical education journal to cater for publications of local studies of mathematics education.

- Invite resource personnel to help conduct Professional Development sessions on different forms of reflective tools for effective teacher reflections

- Organize workshops, seminars, conferences to give opportunity for teachers with 20 years of teaching experience, to share research findings from undertaken projects

- Organize Professional Development sessions on knowledge about types of reflections, and other related reflective skills such as development of the skill of noticing by teachers.

- Pilot group action research in an education district before it could be implemented in other education districts.

\section{REFERENCES}

Chapman.O.(2015). Reflective Awareness in Mathematics Teachers' Learning and Teaching. Eurasia Journal of Mathematics, Science and Technology Education 11(2).pp313-324. http/dx.doi.org/10.12973/Eurasia.2015.1334a

Chen.C.S.(2015). Reflections on Learning How to Teach Mathematics: The Initial Training of Kindergarten Teachers In Creative Education.(6).pp 1328-1335.

Dewey.J.(1933). How To Think: A Restatement of the Relation of Reflective Thinking To The Educative Process. Boston: Heath \& Co.

Dogra.B.(2015).Pre-service Science Teachers' Diaries: Tools for Reflection. Teacher Support 4(3).pp1-17.National Council For Teacher Education. New Delhi-110002. 
Erixon.E.(2016). Learning Activities And Discourses In Mathematics Teachers' Synchronous Oral Discourses Online. Research In Mathematics Education 18(3).pp267-282. http://dx.doi.org/10.1080/14794802.2016.1190667

Farrell. T.S.C.(2004). Reflective Practice In Action. Thousand Oaks. CA. Corwin Press

Fat'hi\&Behzadpour.(2011). Beyond Method: The Rise Of Reflective Teaching. Retrieved on 9th January, 2017 from www.ccseret.org/ijel

Fiji Ministry Of Education.(2011). Annual Report.Suva. Fiji: Government Printers

Groth.R.E.,\&McFadden.J.(2016). Identity Development During Undergraduate Research in Mathematics Education. Mathematics Education 11(2).pp 357375.DOI:10.12973/iser.2016.2110a. ISSN:1306-3030

Hains-Wesson, R. \&Young, K.(2017). A Collaboration Auto ethnography Study to Inform the Reflective Practice in STEM. Higher Education Research and Development, 36(2), 297 310. Retrieved on November 17, 2017 from

http://dx.doi.org/10.1080/07294360.2016.1196653Kaasila.R.\&Lauriala.A. (2012). How Do Pre-Service Teachers' Reflective Processes Differ In Relation To Different Contexts? European Journal Of Teacher Education 35(1).pp77-89. http://dx.doi.org/10.1080/02619768.2011.633992

Krejcie.\&Morgan(1970).Determining Sample Size for Research Activities. Educational and Psychological Measurement.pp607-610.Retrieved on 6th October, 2017 from $\mathrm{http} / /$ research.advisors.com

Kumari V.S.N.,\&Naik S.P. (2015). Effect of Reflective Teaching Training and Teaching Aptitude on Teaching Skills Among Elementary Teacher Trainees In Journal OF Educational Psychology. 9(3),pp11-23

Kumari.V.S.N.(2014). Constructivist Approach to Teacher Education: An Interactive Model for Reflective Teaching. i-manager's Journal of Educational Psychology 7(4).pp31-40. https://doi.org/10.26634/jpsy.7.4.2655

LaBelle, J.T.(2017). Ethical And Political Implications Of Reflective Practice Among PreService Teachers. Reflective Practice, 18(5), 688-698. http://dx.doi.org/10.1080/14623943.2017.1307727

Larrivee, B., \& Cooper. J. M. (2006). An educator's guide to teacher reflection. Boston: Houghton Mifflin Company.

Lambe, J.(2011). Developing Pre-Service Teachers' Reflective Capacity Through Engagement With Classroom-Based Research. Reflective Practice,12(1), 87-100. http://dx.doi.org/10.1080/14623943.2011.541098

Mckay, S. L. (2002). The reflective teacher: A guide to classroom research. Singapore: SEAMEO Regional Language Center. 
Salifu,I.,Worlango,E.K.,\&Kuyini, B.(2017). Classroom Engagement Dynamics: Examining The Potency of Reflective Teaching Approach Among Selected Universities In Ghana. Reflective Practice, 18(6), 725-736. http://dx.doi.org/10.1080/14623943.2017.134373

Sanga.K.(2012). Give Me Another NiuLupu: Enhancing Pacific Education Research Capacity. In Sanga. K.,\&Kidmann. J(Eds.).Harvesting Ideas: Niu Generation Perspectives. University Of The South Pacific. Suva. USP Press.pp8-36

Sather A.C. \& Curl.H.(2014).I Want To Listen To My Students' Lives: Developing An Ecological Perspective. Learning To Teach In Teach Education Quarterly 41(1). pp85103.

Scherrer.J.,\&Stein.M.K.(2012). Effects Of A Coding Intervention On What Teachers Learn To Notice During Whole-Group Discussion. Journal of Mathematics Teacher Education 16.pp105-124. DOI.10.1007/s10857-012-9207-2

Taylan. R.D.,\& da Ponte. J.P.(2016). Investigating Pedagogical Content Knowledge in Action. REDIMAT5(3).pp212-234. http://dx.doi.org/10.14471/redimat.2016 2227

Thomas, R.J.\& Kallanackal, I.J.(2017).Attitude of Student Teachers Towards Reflective Journal Writing for Professional Development. Educational Extracts, 5(1), 9-21 